\title{
A student-run peer-reviewed journal: an educational tool for students in the health sciences
}

This article was published in the following Dove Press journal:

Advances in Medical Education and Practice

15 February 2012

Number of times this article has been viewed

Raywat Deonandan'

Premal Patel ${ }^{2}$

Robyn Winterbottom ${ }^{3}$

'Interdisciplinary School of Health Sciences, University of Ottawa, Ottawa, Ontario, ${ }^{2}$ Faculty of Medicine, University of Calgary, Calgary, Alberta,

${ }^{3}$ School of Medicine, McMaster

University, Hamilton, Ontario, Canada
Abstract: Students at the University of Ottawa, many of whom were targeting a career in medicine, were surveyed to determine their attitudes and expectations regarding a new studentrun peer-reviewed journal for the health sciences. A number of students reported that the existence of the journal would make them more likely to take a class with a written component, while a majority would work harder on that assignment. Those intending to pursue postgraduate or professional studies were most likely to recognize the value to their careers of having a publication history. We argue that student-run medical communication endeavors such as this are beneficial both for enhancing student careers and for contributing to a more thorough educational experience.

Keywords: journal, literacy, publication, student, undergraduate, education

\section{Introduction}

There is a concern among some that society's ability to sustain our heretofore high levels of literacy is being compromised in an era of multimedia distraction. ${ }^{1}$ Coupled with a temptation for instructors to depart from lengthy written assignments, due to increasing class sizes, the trend becomes one of limiting students' options for effective public engagement.

Writing and publishing, especially among medical scientists and within the context of peer-reviewed journals, is acknowledged to be important for career advancement, effective communication with the public and with peers, and demonstrating greater understanding of core material. ${ }^{2}$ Being both a regular author and reader and participating in the arena of public intellectual discourse is a proven tool for intellectual growth and achievement. ${ }^{1}$

This is in contrast to more prevalent methods of student engagement and assessment, like multiple-choice questioning, which students feel requires "surface learning" approaches and lower levels of cognitive processing, such as the ability to reproduce without necessarily understanding. ${ }^{3}$ Evaluation tools and assignments are elements of a learning process that includes grander skills and perspectives, including the building of confidence in writing and in the publication process. ${ }^{4}$

Student engagement through campus-based peer-reviewed journals is a novel and potentially successful strategy for addressing declining literacy standards and for launching young medical science careers. There is concern that participation would be low if there was an assumption that the general quality of student work was poor. ${ }^{5}$ However, by incorporating the existence of the journal with the classroom scheduling
Correspondence: Raywat Deonandan Interdisciplinary School of Health

Sciences, University of Ottawa,

43 Templeton St, Ottawa,

Ontario KIN 6XI, Canada

Tel + I $6 \mid 35625800$ Ext 8377

Fax+l 8666813897

Email ray@deonandan.com 
of assignments that might qualify for publication, a cohesive pedagogical approach might be achieved to alleviate some of these concerns.

This study was undertaken at two points: first, in advance of the launch of a student-run peer-reviewed science journal by the students' association of the Baccalaureate of Health Sciences undergraduate program at the University of Ottawa and, second, approximately 1 year later. The program is noted for its French-English bilingualism and for the tendency of its students to seek entry into medical school as their primary choice of postgraduate career trajectory. Indeed, bilingualism is an important facet of the University of Ottawa's educational model, so must be a focus of any study seeking to measure student experience. The study's intent was to identify preconceived incentives and barriers to students submitting papers to the journal and to measure student expectations of the impact of a publication history on both their educational experiences and their career paths.

\section{Methods}

A link to an online survey consisting of 18 questions was emailed to the 1021 undergraduate students enrolled in the Baccalaureate of Health Sciences program at the University of Ottawa at two points: (1) the middle of the 2009-2010 school year and (2) the beginning of the 2010-2011 year. The mailing list of the student association was employed for this purpose, as all students were emailed a link to an online questionnaire hosted by SurveyMonkey.com. While the program is officially bilingual (French and English), the survey was only available in English, though respondents were native speakers of either language.

The 18 questions covered demographic information and questions pertaining to students' self-rating of their writing abilities, future career plans, the role of writing in their studies and future plans, and the potential value of a student-run peerreviewed science journal. All information was self-reported, and no external confirmation was sought. This is most relevant for self-reported grade point average and writing ability. Table 1 presents a list of covariates that were commonly collected between the two versions of the survey applied in both years.

Basic descriptive and bivariable analyses were then performed, using both the native analytical services of SurveyMonkey.com and SPSS (v 2.0; Microsoft Corp, Redmond, WA).

\section{Results}

In the first round of surveys (2009-2010), among 1021 registered students, 105 (10.3\%) completed the survey, of
Table I Covariates collected in the surveys of the Health Sciences of the University of Ottawa which are shared between the 2009-2010 and 2010-20II versions

\begin{tabular}{l} 
Covariates shared between the 2009-20I0 and 20I0-20II \\
survey versions \\
\hline Age \\
Sex \\
Academic year \\
Language \\
Grade point average \\
Career plans after graduation \\
Belief that a publication is an asset to chosen career \\
Perceived writing ability \\
Likelihood of submitting a paper to a student journal \\
Degree to which the existence of a student journal affects valuation \\
of classes with writing content
\end{tabular}

whom 64.4\% were Anglophone. In 2010-2011, there were 116 respondents (11.4\%). A plurality of respondents (32.7\% in 2009-2010 and 26.3\% in 2010-2011) had a cumulative grade point average corresponding to a "B+" grade; but $43.3 \%$ (in 2009-2010) and 24.6\% (in 2010-2011) claimed to be " $\mathrm{A}$ " students or better. Exactly half rated their writing abilities as "average," whereas 48.1\% (in 2009-2010) and $60.2 \%$ (in 2010-2011) thought they were "above average." Interestingly, in the first year, $37.1 \%$ reported having already been published in a nonclassroom venue, such as a school newspaper.

In 2010-2011, responses were surprisingly almost identical, though the proportion of Anglophones was higher at $83.5 \%$. In both years, the students had a median age of 21 years, with a majority of respondents in their first or second year of studies. A plurality reported being "B+" students in both years.

Students' post-graduation career plans were unsurprisingly skewed toward professional or scholarly endeavors. A majority of students intended to pursue either postgraduate studies, medical school, dental school, law school, or some other unspecified professional program.

Students' attitudes toward publication were seemingly dependent upon their career plans, with those intending to go to medical school much more likely to both recognize the value of a publication and to seek publication $(P<0.001$ and $P=0.006$, respectively). Respondents intending to enter the workforce directly upon graduation, as opposed to those intending to pursue postgraduate or professional training, were the least likely to think that earning a peer-reviewed publication would be of value in achieving their career ambitions.

In 2009-2010, it was encouraging that the prospect of being able to submit to a student-oriented peer-reviewed 
Table 2 Summary of relationships between selected respondent characteristics and their likelihood of submitting an article to a student peer-reviewed journal (2009-2010)

\begin{tabular}{|c|c|c|c|}
\hline \multirow[t]{2}{*}{$\begin{array}{l}\text { Respondent } \\
\text { characteristic }\end{array}$} & \multicolumn{3}{|c|}{$\begin{array}{l}\text { Likelihood of submitting an article } \\
\text { to the student journal }\end{array}$} \\
\hline & $\begin{array}{l}\text { Not likely } \\
\text { n, \% }\end{array}$ & $\begin{array}{l}\text { Either } \\
\text { somewhat or } \\
\text { very likely } \\
\mathrm{n}, \%\end{array}$ & $\begin{array}{l}\text { P-value } \\
\text { (Fisher } \\
\text { exact test) }\end{array}$ \\
\hline \multicolumn{4}{|l|}{ Self-rated writing ability } \\
\hline Above average & $5,10.2 \%$ & $44,89.8 \%$ & 0.024 \\
\hline Average & $15,28.8 \%$ & $37,71.2 \%$ & \\
\hline \multicolumn{4}{|l|}{ Plans after graduation } \\
\hline $\begin{array}{l}\text { Medical or graduate } \\
\text { school }\end{array}$ & $10,12.3 \%$ & $71,87.7 \%$ & $<0.001$ \\
\hline Other & $12,54.5 \%$ & $10,45.5 \%$ & \\
\hline \multicolumn{4}{|c|}{ Have previously published outside of class } \\
\hline Yes & $7,12.5 \%$ & $49,87.5 \%$ & 0.028 \\
\hline No & $15,31.9 \%$ & $32,68.1 \%$ & \\
\hline \multicolumn{4}{|l|}{ Language } \\
\hline English & $10,15.4 \%$ & $55,84.6 \%$ & 0.150 \\
\hline French & $8,29.6 \%$ & $19,70.4 \%$ & \\
\hline
\end{tabular}

journal would make $38.1 \%$ of respondents more likely to take a class that included a written assignment, versus only $3.8 \%$ who thought it would make them less likely to take the class. Further, while a majority (58.1\%) felt it would make no difference to them, a further majority $(53.3 \%)$ reported that the existence of a student journal would encourage them to work harder on a written assignment. Those questions were not posed in the 2010-2011 version as the journal was already up and running by that point.

Tables 2 and 3 present summaries of selected covariates (from 2009 to 2010 and 2010 to 2011, respectively), which

Table 3 Summary of relationships between selected respondent characteristics and their likelihood of submitting an article to a student peer-reviewed journal (2010-20II)

\begin{tabular}{llll}
\hline $\begin{array}{l}\text { Respondent } \\
\text { characteristic }\end{array}$ & \multicolumn{2}{l}{$\begin{array}{l}\text { Likelihood of submitting an article } \\
\text { to the student journal }\end{array}$} \\
\cline { 2 - 4 } & $\begin{array}{l}\text { Not likely } \\
\mathbf{n}, \%\end{array}$ & $\begin{array}{l}\text { Either } \\
\text { somewhat or } \\
\text { very likely } \\
\text { n, \% }\end{array}$ & $\begin{array}{l}\text { P-value } \\
\text { (Fisher } \\
\text { exact test) }\end{array}$ \\
\hline $\begin{array}{l}\text { Self-rated writing ability } \\
\text { Above average }\end{array}$ & $23,48.9 \%$ & $24,51.1 \%$ & 0.035 \\
$\begin{array}{l}\text { Average } \\
\text { Plans after graduation }\end{array}$ & $23,74.2 \%$ & $8,25.8 \%$ & \\
$\begin{array}{l}\text { Medical or graduate } \\
\text { school }\end{array}$ & $14,41.2 \%$ & $20,58.8 \%$ & 0.006 \\
Other & $32,72.7 \%$ & $12,27.3 \%$ & \\
$\begin{array}{l}\text { Language } \\
\text { English }\end{array}$ & $40,58.8 \%$ & $28,41.2 \%$ & 1.000 \\
French & $6,60.0 \%$ & $4,40.0 \%$ & \\
\hline
\end{tabular}

might affect students' intent to submit an article to a journal. Self-rated writing ability, post-graduation career trajectory, and reported experience with publishing all contributed positively to the likelihood of writing for a journal, whereas linguistic community of origin had no statistical bearing.

\section{Discussion}

In a systematic review of interventions designed to increase academic publication rates, an Australian team identified writing courses, writing support groups, and writing coaches as popular strategies for encouraging publication among academics. ${ }^{6}$ Ease of submission, or the simplification of the process to transition an assignment into a publication, can also be an important factor in maximizing the probability of publication. ${ }^{7}$ A student journal represents one manifestation of the simplification process. At least one study ${ }^{4}$ suggested that "[s]tudent journals enhance student learning and promote publication" by being a form of mentorship external to a formal classroom setting.

The value of a student journal goes beyond its ability to promote publication and expression. The reading of wellwritten and well-conducted scientific information is presumably educationally beneficial and there is an argument that students would be more likely to read a publication produced by themselves or their peers. Moreover, there is evidence that the reading of student journals confers a measurable increase in knowledge of the general subject area covered by the journal. ${ }^{8}$

Research leading to publication has been stated as the most important second-order criterion for admission to graduate school $^{9}$ and students with research involvement have reported clear employability benefits. ${ }^{10}$ Increasingly, medical school admissions committees are considering a record of published research when assessing an applicant's characteristics. The extent to which students are aware of this trend may influence the degree to which they learn to value both writing and publishing as important skill sets.

Despite the limited sample size of our study, it is nonetheless encouraging that regardless of whether a student ranked his or her writing ability as average or above average, he or she was likely to submit to the journal, though those who thought they were above average were most likely to do so. As a corollary, it is curious that almost half of the respondents felt that their ability was above average, a sentiment that would be interesting to test objectively.

While the content of the survey changed slightly from 2009-2010 to 2010-2011, it was still not surprising that the results of the essential overlapping questions did not 
change: students' future plans were still skewed toward medical and graduate school, students still tended to rate their writing abilities above average, and there was still an association between both career path and perceived writing ability with reported valuation of a peer-reviewed journal. Of course, given the poor response rate in both surveys, it is not possible to reliably conclude that these results truly reflect the general student experience.

Most encouraging among these data is the finding that a fair proportion of students would be more likely to take a class with a written assignment component, and to be more enthusiastic about that written assignment, with the knowledge that a student journal exists to accept and publish the most impressive of their products. This represents an inexpensive and passive tool to improve student written engagement.

Given the University of Ottawa's strong focus on bilingualism, ${ }^{11}$ it was important that opportunities and outcomes be well distributed amongst both linguistic groups. The fact a majority of respondents were Anglophone reflects the majority Anglophone enrollment of approximately $75 \%$; however, it is nonetheless heartening that linguistic origin had no statistical relationship with students' intention to participate in the journal. This statistic will be revisited, and hopefully recapitulated, when the students' papers are eventually submitted and published.

The value of a student journal for educators appears to be in its ability to both marshal student enthusiasm for writing and for writing assignments. This enthusiasm is probably driven by the promise of a publication record, which is accurately perceived to be an advantage in the competitive process of applying to medical and other professional schools.

A possibility not explored in this study is the potential value of a journal in providing a standard or goal to which educators can direct written assignments. A classroom assignment involving a systematic literature review, for example, can be targeted to produce work of sufficient quality to be submitted to the student journal. This may provide a useful threshold for harmonizing assignment quality across courses and sections, which is always a desirable teaching and administrative outcome.

While these data describe the experiences and attitudes of undergraduate students, a number of whom are considering a career in medicine, the lessons likely apply to those already undergoing medical education as well. Increasingly, the value of writing, peer-reviewed publishing, and the management of student-run endeavors in medical communication are being recognized not only as useful in improving a student's career prospects, but also for enriching the education experience itself.

\section{Conclusion}

Literacy, engagement with the scientific literature, and a comfort with general medical communication are essential for an effective medical education and career. With declining literacy rates befalling classrooms, novel interventions and programs are necessary to encourage science communication literacy. With a vibrant publication history continuing to be an important predictor of a successful professional career, the support and encouragement of student writing, through such innovations as student-run peer-reviewed journals, becomes preeminent within society's larger pedagogical mandate. The data herein suggest that not only are health science students likely to value such ventures but also that such opportunities may also serve as an incentive for greater efforts in classroom-based written assignments.

\section{Disclosure}

The authors report no conflicts of interest in this work.

\section{References}

1. Clarkson B. Literacy rate hits $85 \%$. The Toronto Sun. June 4, 2009. Available from: http://www.torontosun.com/news/canada/ 2009/06/04/9670181-sun.html. Accessed September 27, 2010.

2. Riegelman RK. Effects of teaching first-year medical students' skills to read medical literature. J Med Educ. 1986;61(6):454-460.

3. Scouller K. The influence of assessment method on students' learning approaches: multiple choice question examination versus assignment essay. Higher Education. 1998;35(4):453-472.

4. Pearson JA, Van Nest RL, Jasinski DM. Promoting publication by producing a student journal. Nurse Educ. 2004;29(2):68-70.

5. Timmons S, Park J. A qualitative study of the factors influencing the submission for publication of research undertake by students. Nurse Educ Today. 2008;28(6):744-750.

6. McGrail MR, Richard CM, Jones R. Publish or perish: a systematic review of interventions to increase academic publication rates. Higher Educ Res Dev. 2006;25(1):19-35.

7. Sbaih L. Helping students convert assignments into articles: tips for teachers. Accid Emerg Nurs. 1999;7(2):112-113.

8. Christ J, Cutier R, Mahrs R, Jasinski D, Pearson, J. A published student journal: effect on graduate students of nurse anesthesia. AANA J. 2006;74(6):433-439.

9. Keith-Spiegel P, Tabachnick B, Speigel G. When demand exceeds supply: second-order criteria used by graduate school selection committees. Teaching Psychol. 1994;21:79-81.

10. Walkington $\mathrm{H}$. Geoverse: piloting a national e-journal of undergraduate research in Geography. Planet. 2008;20:41-46.

11. University of Ottawa. Regulation on Bilingualism at the University of Ottawa, 1974. Available from: http://web5.uottawa.ca/admingov/ bilingualism.html. Accessed September 27, 2010. 
Advances in Medical Education and Practice

Dovepress

\section{Publish your work in this journal}

Advances in Medical Education and Practice is an international, peerreviewed, open access journal that aims to present and publish research on Medical Education covering medical, dental, nursing and allied healthcare professional education. The journal covers undergraduate education, postgraduate training and continuing medical education including emerging trends and innovative models linking education, research, and healthcare services. The manuscript management system is completely online and includes a very quick and fair peer-review system. Visit http://www.dovepress.com/testimonials.php to read real quotes from published authors.

Submit your manuscript here: http://www.dovepress.com/advances-in-medical-education-and-practice-journal 